原 著

順天堂医学 38 (3)

P. $380 \sim 392(1992)$

\section{精神分裂病の臨床経過と事象関連電位 **}

Changes in event-relatad potentials during the course of schizophrenia

\author{
文元 秀 雄* \\ Hideo FUMIMOTO, M.D.
}

DSM III R 亿従って診断された精神分裂病（以下 分裂病）患者10名について, BPRS, SANS 等で臨床症状を詳細に評価しながら, odd-ball 課題での事象関連電位 (Event-Related Potentials : ERP) を向精神薬未服薬の時点加記録し, 臨床経過と N 100 成分, P 300成分の変化に ついて縦断的に検討した。

緊張型と妄想型の各 2 名は, 症状の軽快とともに P 300振幅が増大する傾向が認められたが, 解体型と残遺型の計 6 名では, P300振幅の変動は症状の変化と一定の関係を持たず, 概して低振 幅であった。また, 社会適応度の中間群ないし不良群では, 社会適応良好群に比べ, 非目標刺激 時の ERP において P 300成分が高頻度で出現した.また最も適応の悪い群では, 目標・非目標 の両刺激ともにP300成分は認められなかった。

分裂病の認知障害において, 緊張型と妄想型では治療反応性が高いが, 解体型と残遺型には治 療抵抗性の要素があり, 病態が前 2 者と異なると考えられた。 そして非目標刺激時のP P 300の検 討から, 認知構造の解体度が社会適応状況湆響する可能性が示唆された。

キーワード : 精神分裂病, 社会適応度, 事象関連電位, P300

Key words : schizophrenia, social adaptation level, event-related potentials, P300

\section{緒言}

精神分裂病（以下 分裂病）における生物学的 研究のなかで, 認知情報処理論的アプローチが近 年急速に発展し, 分裂病研究の主要な分野として その地位を固めつつある.

精神作業を負荷した時の脳内情報処理過程を反 映する神経生理学的指標である事象関連電位 (Event-Related Potential；ERP)，とくにP300成分 については, Sutton ら ${ }^{1 /}$ が1965年に同成分を初め て報告した後, 認知障害の観点から捉えた分裂病 の研究に応用され，既に多数の報告がある.乙れ

* 順天堂大学医学部精神医学教室

Department of Psychiatry, Juntendo University School of Medicine, Tokyo, Japan

〔Nov. 11，1991 原稿受領〕（Nov. 28, 1991, 揭載决定）
らの報告のなかでほぼ共通している所見は, 分裂 病者の場合 P300成分の振幅が健常者に比較して 小さ(2) 17) ととである.

また, 分裂病の認知障害に関して治療的側面か ら考える場合, 治療による臨床症状の変化と, ER $\mathrm{P}$ 各成分の変化との関連についての検討が必要で ある. その際, 患者個人内での縦断的な検討が不 可欠となる.乙の方面では幾つかの報告がある が911819), 多くは短期間の観察であり, ERP 記録 時期も, 患者の病状によらず一律に定められたも のが多い.しかしながら, 分裂病は多様な症状と 経過を有する疾患であるから，臨床症状の細かい 変動を評価しながら, 個々の経過に即した長期間, かつ縦断的な ERP 成分の観察が重要である. して将来的に個々の分裂病者の病態の把握や, 薬 物等による治療効果の判定, ひいては臨床経過を 予測していくという, いわば機能的指標として 
ERP を活用するためにも欠かせない研究方法で あるが, 現在のところそのような方法に基づいた 報告はない。

以上の観点から著者は, さまざまな分裂病患者 について個別に, 向精神薬未服薬の急性期より簡 易精神症状評価尺度（BPRS），ならびに陰性症状 評価スケール（SANS）等を用いて臨床症状を詳 細に評価し, odd-ball 課題での ERP とくに N10 0成分, P300成分を長期間の臨床経過のなかで観 察した. その結果, 分裂病の横断的特徵と経過を 表現するうえで現在最も有力な標識である病型や， 治療的指標の一つである社会適応の状況に関連し た $\mathrm{P} 300$ 成分の変化が認められたので, 乙れを報 告するとともに, 分裂病の病態について認知障害 の観点から考察した。

\section{対象および方法}

対象は, 1989年 9 月から 1991年 7 月までの期間 中に, 順天堂越谷病院に外来通院か, 入院して治 療をうけた精神分裂病患者 10 名（男 7 名 女 3 名） で, 年齢は 18 歳から66歳（平均 34.7 歳）である. 診断は DSM III R 亿基づいた. 病型分類では 2 名 が緊張型 2 名が妄想型 3 名が解体型 3 名が残 遺型に該当した。平均罹病期間は 10.7 年であった。
全例向精神薬未服薬の状態での ERP 記録と, 複 数の医師による BPRS および SANS 要約得点 を用いた臨床症状評価を並行して行った. 以後個々 の経過中, 臨床的に変化が認められる時点で, 随 時 ERP 記録と症状評価を実施した。観察期間と しては, 未服薬時から諸治療により状態がほぼ安 定化した時期までとした。 また全例について, 分 裂病発症以後の社会適応度を江熊の基準 ${ }^{20}$ 亿従い, 自立 (A) 半自立 (B) 家庭内適応 (C) 適応不能 (D) 入院 (E) の 5 段階に評価した. 対象の内 4 名が $\mathrm{B}, 1$ 名が $\mathrm{C}, 5$ 名が $\mathrm{E}$ 亿該当した（表-1). 入 院中の者については, 必ずしも通院中の者より状 態力゙悪いとはいえない2122)ととから, 臨床像・生 活態度・作業能力等の要素 ${ }^{21)}$ 考慮し, 臨床経過 から推定して修正した評価を, 表- 1 の括弧内に示 した.これに従うと, 例えば表中の E（E）とは今 後も入院が必要と推定される状態を示し, 社会適 応度は最も不良な水準にあると考えられる。

初回記録以後は全例向精神薬を服薬したが, 抗 精神病薬以外の薬物（抗不安薬・抗パーキンソン 薬等）の種類と量は各症例の治療経過中, 原則と して固定した.

健常対照者は, 上記の対象の性比と年齢にほほ マッチした20名で, 精神科的遺伝負因や精神神経 疾患の既往がなく, 服薬もしていない者とした。

表- 1 対 象

\begin{tabular}{|c|c|c|c|c|c|c|c|c|}
\hline 症例No. & 性 & 年㯪(歳) & 病型 & 罹病期間 & BPRS評点 * & SANS要約得点" & 主 症 状* & 発症後の社会適応度 ${ }^{* *}$ \\
\hline 1 & 男 & 30 & 解体型 & 5 年 & 57 & 9 & $\begin{array}{l}\text { 幻聴, 被害関係安想, 思考伝播 } \\
\text { 作為何験 }\end{array}$ & B \\
\hline 2 & 男 & 27 & 解体型 & 0.5 年 & 49 & 14 & $\begin{array}{l}\text { 幻聴, 被害開係妄想, 注察妄想 } \\
\text { 考想祭知, 自発性低下 }\end{array}$ & $E(C)$ \\
\hline 3 & 女 & 42 & 緊張型 & 16年 & 53 & 15 & $\begin{array}{l}\text { 関係念虑，思考途絶，亜昏迷 } \\
\text { 想気分 }\end{array}$ & B \\
\hline 4 & 女 & 49 & 緊張型 & 14年 & 37 & 12 & $\begin{array}{l}\text { 滅裂, 精神運動性興蓄 } \\
\text { ときに亜昏迷 }\end{array}$ & B \\
\hline 5 & 男 & 18 & 残遺型 & 5 年 & 53 & 7 & $\begin{array}{l}\text { 被害関係妄想, 家庭内暴力 } \\
\end{array}$ & c \\
\hline 6 & 男 & 25 & 残遺型 & 9.5 年 & 39 & 10 & $\begin{array}{l}\text { 被害関係念虑, 幻聴, 感情の平板化 } \\
\text { 自閉 }\end{array}$ & B \\
\hline 7 & 男 & 27 & 妄想型 & 4 年 & 46 & 8 & 被害関係妄想, 幻聴 & $E(C)$ \\
\hline 8 & 男 & 35 & 残遗型 & 15年 & 41 & 16 & $\begin{array}{l}\text { 被害妄想, 抑うつ気分, 自発性低下 } \\
\text { 自数念慮 }\end{array}$ & $E(D)$ \\
\hline 9 & 男 & 28 & 妄想型 & 5 年 & 37 & 3 & 被害関俰妄想, 易刺激性 & $E(C)$ \\
\hline 10 & 女 & 66 & 解体型 & 33年 & 67 & 17 & 無為, 自閉, 連合弛緩 & $E(E)$ \\
\hline
\end{tabular}


年齢は18歳から59歳（平均33.1歳）で, 性別は男 性14名と女性 6 名であった。

ERP の測定は, 日本脳波筋電図学会の誘発電 位測定指針 $\left.{ }^{23}\right)$ 亿従い, odd-ball 課題を用いて実施 した. 音刺激は聴性誘発反応用音刺激装置（日本 電気三栄2426）を用い, 非目標刺激である $1000 \mathrm{~Hz}$ の音刺激は提示確率 $0.75 \sim 0.85$, 目標とする 2000 $\mathrm{Hz}$ の音刺激は, $0.15 \sim 0.25$ の提示確率でランダ ムに出現する刺激系列を用いた。 被験者の正答率 が70\%を下回った場合は課題遂行に問題があると して, そのブロックの成績は除外した。

脳波は銀一塩化銀電極を用い, 両側耳架連結を 基準電極として, 国際式10-20法に基づき $\mathrm{Fz} \mathrm{Cz}$ $\mathrm{Pz}$ より単極導出した. 記録条件は, 高周波数フィ ルタを $120 \mathrm{~Hz}$ （時定数 $0.3 ）$ として増幅し, EOG とともに記録した。解析は医用マイクロコンピュー 夕（日本電気三栄 7 T 18）を用いて, 各症例につ き低頻度刺激40回・高頻度刺激40回の平均加算を 行い ERP 波形を求めた. その際 $\pm 100 \mu \mathrm{v}$ 以上の EOG が出現した施行は除外した。

ERP 成分は, 刺激開始点より各成分の頂点ま での時間を潜時, 刺激前 $100 \mathrm{msec}$ の区間の平均電 位を基準とした各成分の頂点までの電位を（最大） 振幅とした. その上で潜時70〜 150msec 間の最大
陰性頂点を $\mathrm{N} 100$, 同様に潜時 $260 \sim 460 \mathrm{msec}$ 間の 最大陽性頂点を P300とした。 また, 今回は非目標 刺激時の P 300 成分を, 目標刺激時の同成分との 潜時の差が50msec 以内で, $3 \mu \mathrm{V}$ 以上の振幅を有 するものと定義し, 視察法で同定した.

記録は生物学的日内変動を考慮し, 午前 10 時か ら午後 3 時までの日中に行った。

なお被験者には，研究の趣旨と内容を説明し， 同意を得た上で実施した。

統計学的有意差の検定には, student- $\mathrm{t}$ 検定 (両側)，ならびに 2 群間の百分率の差の検定を用 いた。

\section{結 果}

各対象の $\mathrm{Pz}$ 導出の $\mathrm{P} 300$ 成分の振幅について, さまざまな傾向が認められたので, 詳細を以下に 順次示す。なお, 著者の 10 例の検討では, N100成 分の潜時と振幅, ならびにP300成分の潜時と臨床経 過との間には, 一定の傾向は認められなかった.

1. 臨床経過と P 300 成分の振幅の变化および $\mathrm{Pz}$ 導出の ERP 原波形

臨床経過と P 300 成分の振幅の変化を, 各病型 の代表例について具体的に呈示する.

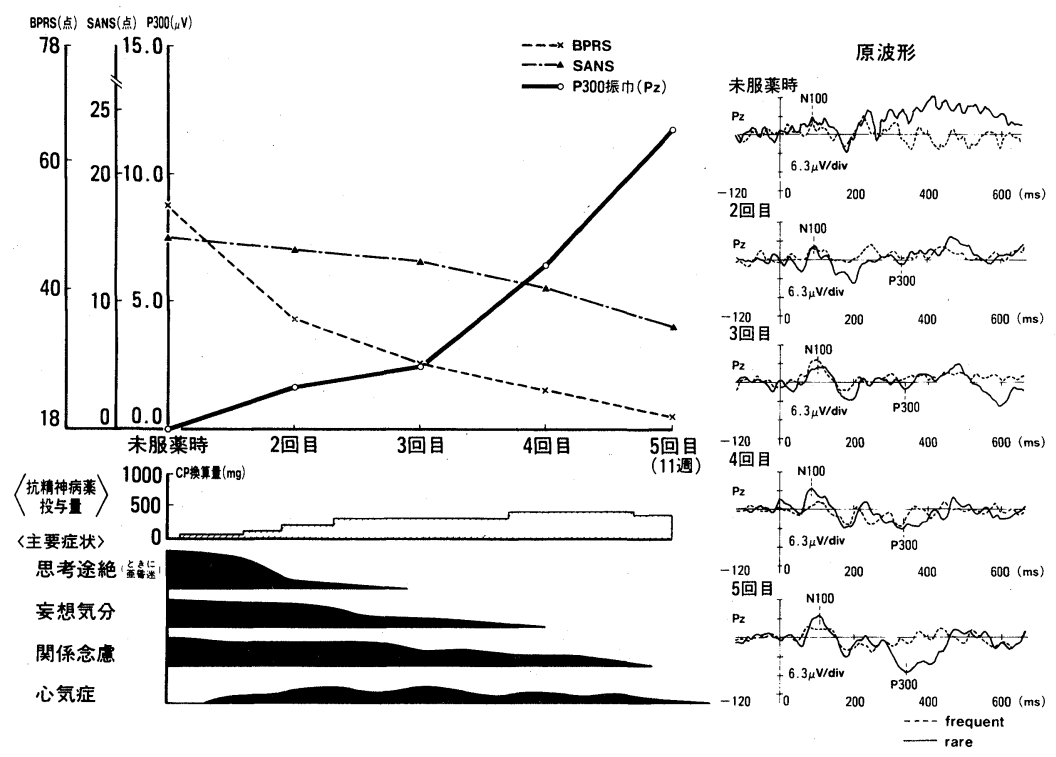

図- 1 症例 3 (女性 42歳 緊張型) に扔引る臨床経過と P300振幅（Pz導出） 


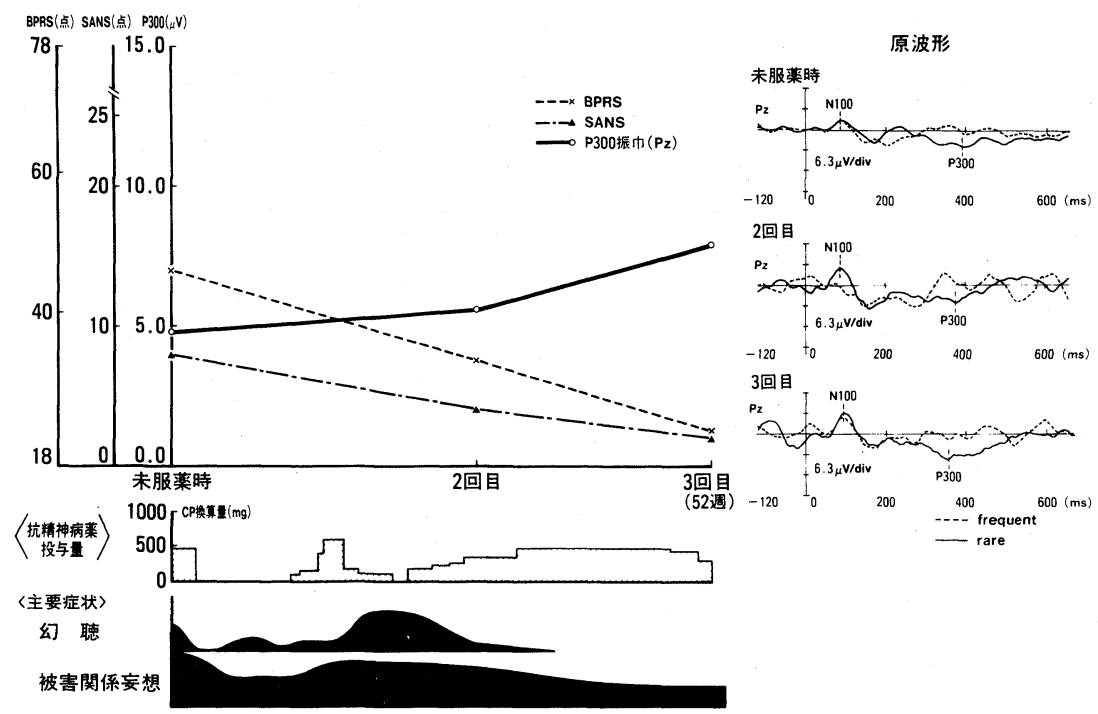

図- 2 症例 7 （男性 27歳 妄想型）における臨床経過とP300振幅（Pz導出）

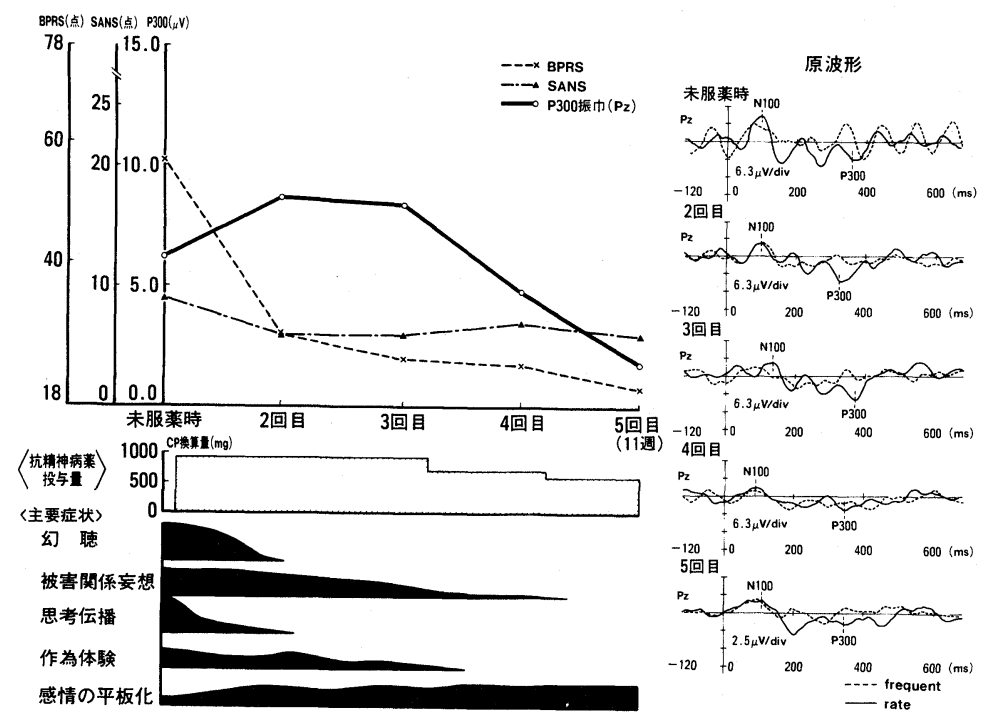

図- 3 症例 1 （男性 30歳 解体型）における臨床経過とP300振幅（Pz導出）

\section{A. 緊張型 (図-1)}

42 歳女性で事務職. 24,5歳の発症. 昏迷状態を主 とする精神運動性障害が前景化し, 数回の入院歴 があるものの, その都度短期間で軽快し長期の就 労が可能だが, 寬解期においても若干の情意障害 を認める. 今回は服薬の中断後, 徐々に妄想気分
と関係念慮が出現し, 遂には昏迷状態となり入院 したが, chlorpromazine (CP) を最大で $350 \mathrm{mg}$ 投 与して軽快し, 退院後約半年で復職した. 全体と $し て$, Conrad $^{24)}$ のう異常意味啓示相期まで到達 しながらも，エネルギーポテンシャルの減退の少 ない経過と考えられる。 
本症例の場合観察期間は 17 週に亘ったが，図-1 のように BPRS・SANS 要約得点の減少, ならび に主要精神症状の軽減とともに P 300 振幅が増大 した。

B. 妄想型 (図-2)

27 歳男性で無職. 23 歳頃の発症. 当初は職場の 同僚に対する関係念慮が中心であったが, 次第に
体系だった被害関係妄想に発展し，同僚や上司と 衝突し退職した。 その後は徐々に家族を取り込ん だ被害関係妄想や幻聴が出現し，しばしば家庭内 で暴力的となった. 26 歳時より入退院を繰り返し ていたが, 今回も家庭内暴力のため看護困難とな り入院となった. propericiazine, levomepromazine (LPZ) を主剈として, $\mathrm{CP}$ 換算で最大 $500 \mathrm{mg}$ の投

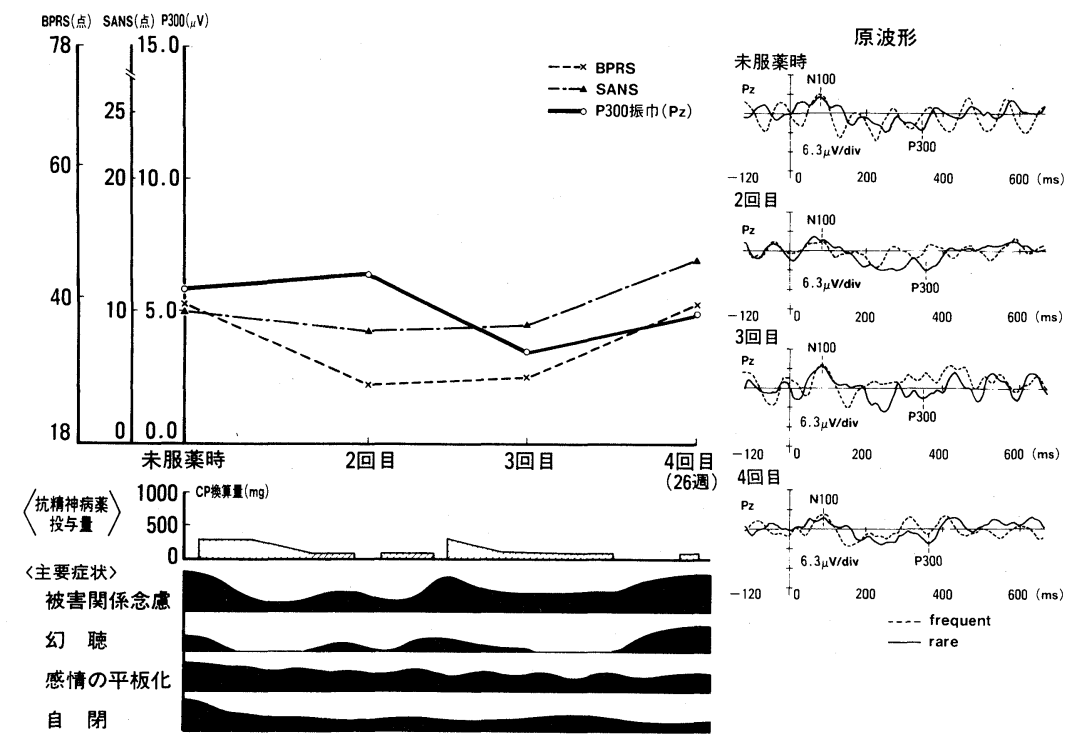

図-4. 症例 6 (男性 25歳 残遺型) に打厰床経過と P300振幅 (Pz導出)

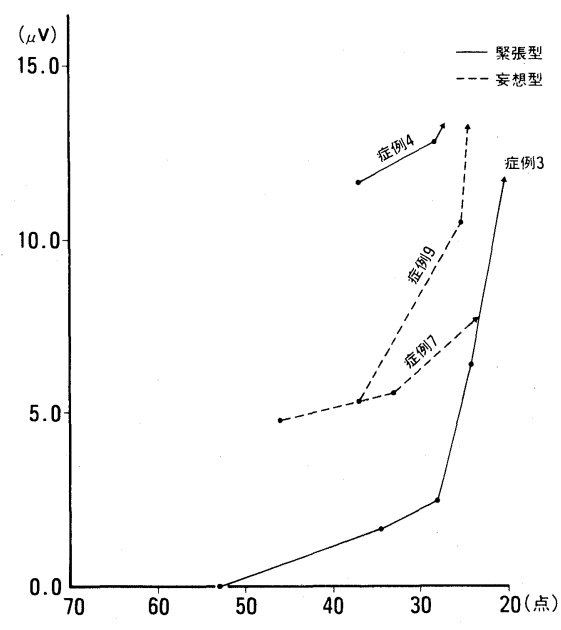

A. 緊張型·妄想型

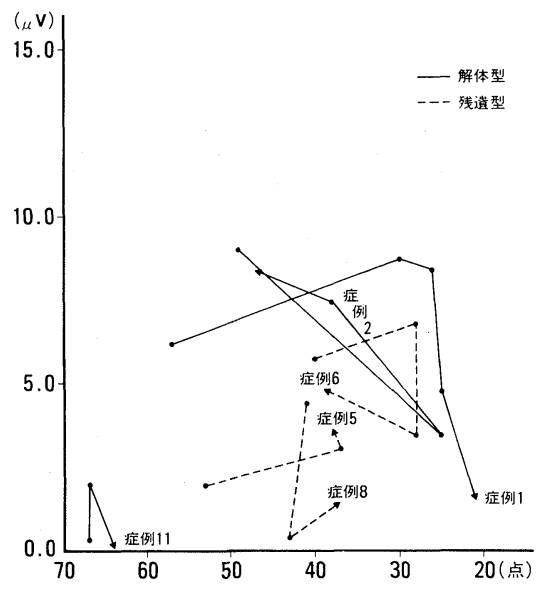

B. 解体型·残遺型

図- 5 . BPRS 得点と P300 $(\mathrm{Pz})$ 振幅との関係 
与で幻聴は消失し, 病棟内での生活に問題はなく なった、情意障害も目立たない.しかしながら家 族に対する被害関係妄想は不変で, 現在も入院中 である. Conrad でいえば, 異常意味顕現〜啓示 期から慢性に経過したと考えられる.

本症例の場合も図-2に示すように, 緊張型ほど 大きい変化ではないものの, やはり症状の軽快と ともに P300振幅は増大している.

\section{C. 解体型 (図-3)}

30歳男性で, 現在は就労している. 25歳前後の 発症. 神秘的で魔術的な思考に支配され, 被害関 係妄想や連合弛緩が前景化し, 後には対話型式の 幻聴・思考伝播・作為体験といった Schnider の 一級症状を呈して入院となった. haloperidol（H $\mathrm{PD}) \cdot \mathrm{CP} \cdot \mathrm{LPZ}$ を主剤として, CP 換算で最大 $900 m g$ の投与にて陽性症状は軽快したが, 感情の 平板化や自発性の低下等の障害が残存した。退院 後は通院が不規則で, 症状は一進一退であるが, 勤務状況ないし社会適応は良好である. 全体では, ほほ Conrad のいう破瓜型の経過に相当すると 考えられる.

本症例の場合図-3に示すように, 投薬開始後 2 回目の記録では, BPRS 得点の大幅な減少にとも ない P300振幅は増大したものの, 以後の記録で は, BPRS 得点の減少とともに P 300 振幅も減少 した. 全経過を通じても, P300振幅の変動と症状 との関係で一定の傾向は認められなかった。しか しながら振幅自体は，概して低振幅の傾向を認め た.

\section{D. 残遺型 (図-4)}

25歳男性で倉庫の管理に従事している.15歳頃 の発症. 会社の同僚に対する被害関係念慮が中心 で，ときに幻聴も出現するが仕事の妨げとなるほ ど重篤なととはほとんどない，しかし感情の平板 化や自発性低下，そして自閉傾向はほぼ固定化し ており, 慢性期の状態にある. 少量の HPD 服薬 で軽快したが病識に乏しく，外来通院も不規則で ある. 経過としては, Conrad の破瓜型に準ずる が,よりエネルギーポテンシャルの減退が顕著な ものである.
本症例も図-4の通り, 経過中 P 300振幅は一貫 して低振幅であるが, やはり症状との関係に一定 の傾向は認めない。

2. BPRS 得点と $\mathrm{P} 300$ 振幅 $(\mathrm{Pz}$ 導出) との関 係 (図-5)

全対象をP300振幅の変化における傾向から, 緊張型・妄想型と, 解体型・残遺型との 2 群に分 け, BPRS 得点の変化と P 300 振幅の変化との関 連について検討した。

A. 緊張型・妄想型（図-5A.）

緊張型と妄想型の各 2 名では全て, P 300 振幅が 右上がりの変動が認められた.すなわち BPRS 得点が減少するに従い P300振幅が増大していっ た。

B. 解体型・残遺型（図-5B.）

解体型と残遺型の各 3 名では, BPRS 得点が減 少しても $\mathrm{P} 300$ 振幅の変化に一定の傾向は認めら れなかった.しかしながら緊張型と妄想型の群と 比べ, 概して低振幅を示した。

3 . SANS 要約得点と $\mathrm{P} 300$ 振幅 $(\mathrm{Pz}$ 導出) と の関係

全対象について, SANS 要約得点の変化と P300 振幅の変化との関連を検討したが, 特徵的な傾向 は認められなかった。

4. 健常対照者を含めた各群間でのP P 300 振幅 ( $\mathrm{Pz}$ 導出) の比較（図-6)

前述したように, 全対象を緊張型・妄想型と解 体型・残遺型の 2 群に分け, 健常対照群と合わせ た 3 群の間で, P300振幅の分布を比較した. 図- 6 は各群において, 服薬および病状の如何にかかわ らず, P300振幅の全記録をブロットしたものであ る. 分裂病者の 2 群は, 健常対照者の群と比べて 明らかに低振幅で分布したが，とくに解体型・残 遺型とは有意差が認められている. また分裂病者 の 2 群間でも, 解体型・残遺型が有意に低振幅で あった. (ただし分裂病者の記録には, 同一の対象 で複数回記録したものが含まれる)

\section{5 . 社会適応度と目標・非目標刺激時 ERP}

対象となった分裂病者の, 発症以後の社会適応 度をふまえながら, 経過中の ERP を検討した。 


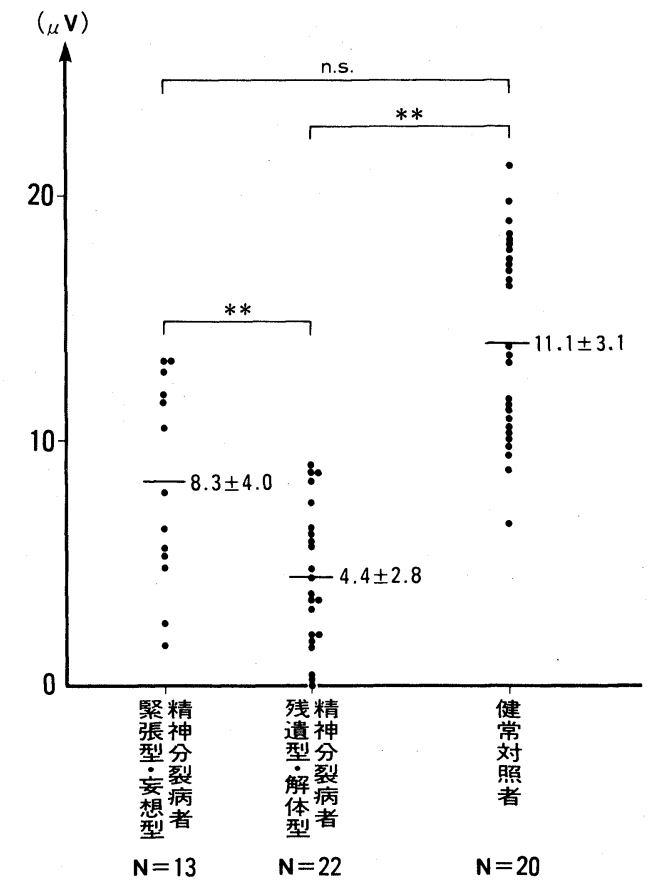

図- 6 P300 成分の振幅 $(\mathrm{Pz})$

図中の横棒は平均値（数值は mean $\pm \mathrm{SD}$ ) を示す.

**は $\mathrm{P}<0.01$ 亿て有意差があるてとを表す, 有意差検定には各 群との間で対応のない $\mathrm{t}$ 検定を用いた。 n.s. : not significant

今回著者は, 適応度の水準をより理解しやすくす る目的から, 対象の社会適応度を次のように再分 類した. すなわち, 自立と半自立 (A.B) を社会 適応良好群・家庭内と適応不能, ならびに入院中 $[\mathrm{C}, \mathrm{D}, \mathrm{E}(\mathrm{C}), \mathrm{E}(\mathrm{D})]$ を社会適応中間または不良 群, 入院中〔E (E) 〕を社会適応最不良群とした. 対象の内では, 症例 No.1 $34 \quad 4 \quad 6$ の 4 名が社会 適応良好群に, また症例 No.2 $5 \begin{array}{llll}5 & 7 & 8 & 9\end{array}$ 名が同中間または不良群に，そして症例 No.10の 1 名が同最不良群に該当した. 以上の結果は表- 2 に示す通り, 非目標刺激時 ERP では, 社会適応 良好群の 17 回の記録中, 2 回だけP 300 成分が $\mathrm{Pz}$ 導出で出現したのに対し, 中間または不良群では 16回の記録中, 特定の症例に偏るととなく10回に, 同成分が $\mathrm{Pz}$ 導出で出現した. また社会適応最不 良群の 1 例では, 3 回の記録中一貫してP 300 成分 は出現しなかった. 以上 3 群における非目標
表-2 臨床経過中に認められた非目標刺激時 P300成分 $(\mathrm{Pz})$ の出現頻度

\begin{tabular}{|c|c|c|c|}
\hline 対象（社会適応度） & $\begin{array}{l}\text { ERP記録 } \\
\text { (回) }\end{array}$ & $\begin{array}{ll}\text { 非目標刺激時に出現した } \\
\text { P300 } & \text { (回) }\end{array}$ & $\begin{array}{c}\text { 出現頻度 } \\
(\%)\end{array}$ \\
\hline $\begin{array}{l}\text { 分裂病 (社会道応良好群) } \\
N=4\end{array}$ & 17 & 2 & 11.8 \\
\hline $\begin{array}{l}\text { 分裂病 (社会逼心中間または不良群) } \\
N=5\end{array}$ & 16 & 10 & $62.5^{*}$ \\
\hline $\begin{array}{l}\text { 分裂痌 (社会適応最不良群) } \\
\mathrm{N}=1\end{array}$ & 3 & 0 & 0.0 \\
\hline $\begin{array}{c}\text { 健常 对照群 } \\
N=20\end{array}$ & 20 & 4 & 20.0 \\
\hline
\end{tabular}

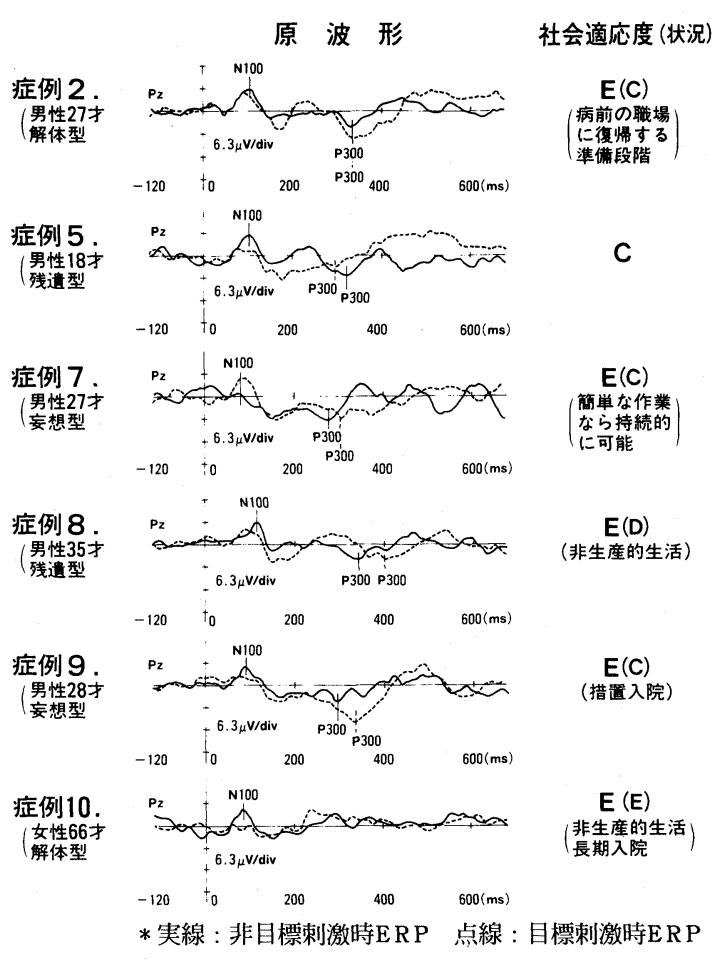

図- 7 社会適応中間または不良群および最不良群の $\mathrm{E}$ $\mathrm{RP}$ (非目標刺激時 : Pz)

刺激時 P 300成分の出現頻度を健常対照群と比較 すると, 社会適応中間または不良群で有意に高かっ た (同一対象で複数回記録したものを含む). 社会 適応中間または不良群, および最不良群における 非目標刺激時 ERP 原波形の典型例と, 社会適応 の具体的な状況を図-7亿示した。なお, 各導出に おける非目標刺激時 N100・P300の潜時, 振幅の 
変化と社会適応度との関連については, 一定の傾 向は認められなかった。

一方, 目標刺激時 ERP に関しては, 社会適応 最不良群の 1 例で, 各導出とも P 300 成分は一貫 して出現しなかった. その他の対象では, 経過中 に出現した各導出の目標刺激時 N100成分・P300 成分の潜時・振幅とも, 社会適応度と関連した変 化は認められなかった。

なお, $\mathrm{Fz} \mathrm{Cz}$ 導出の P300に関しては, 以上 1 〜 5 を通じて症状との有意な関連は得られなかった。

\section{考察}

\section{ERP による分裂病研究の従来の問題点}

現在, 分裂病という精神疾患を考える際, 依然 として基本になるのは, E. Kraepelin および $\mathrm{E}$. Bleuler による疾患概念である.すすおち Kraepeline による早発性・進行性・㾰呆化という一連の 経過図式と, Bleuler による連合弛緩・感情障害・ 自閉・両価性といった横断的な 4 つ基本症状を 2 本の柱としながら，その症状と経過については 幅広い多様性が観察されてきた.しかし今日では, 疾患概念としての分裂病の包含範囲がいささか広 大に過ぎていて, 横断面と縦断的経過の明確な関 係づけという, いわば根本病理が依然曖昧なまま である.そしてその解明のためには, 常に縦と横 を整理しつつ両者の関係について検討することが 重要であり, 精神病理学的・心理学的側面にとど まらず生物学的側面からも，同様の手段を基に研 究がなされることが望ましい。

認知心理学は1950年代より欧米を中心に急速な 発展を遂げ, 認知情報処理障害を分裂病の主要な 基本障害とする見方が確立されつつある. このよ うな背景から, 認知情報処理機能の生理学的指標 の一つとされる事象関連電位を用いた分裂病研究 が, 近年盛んになっているのは周知の事実である. てれらの報告のうち現在主なものとしては, 健常 者と比べてN100成分が低振幅で3)7) 9/11) 13/15)16/25), 選択的注意を要する課題でも振幅が増大せず5116), この時のP200成分の振幅も低下しない ${ }^{716)} と と$,
P200成分も低振幅 ${ }^{13)}$ で潜時が短縮している P300成分も同様に健常者と比べ低振幅である が2) 17), 潜時には有意な差がないてと早1013114)17)26), 等がある.とれらのことから分裂病者では, 選択 的注意 ${ }^{3(5) 7) ~ 9(11) 15(16) 25)} \cdot$ responce set $^{27 / 28)}$ ・刺激評 価 $^{29 \sim 32)}$ ・ 概念化 ${ }^{30)}$ ・ 反応選択 ${ }^{19)}$ ・認知文脈の更 新 ${ }^{33}$ (34) ・ 刺激処理に対する制御過程 ${ }^{35}$ )36)等の障害 が示唆されている.しかし以上の検討のほとんど は, 横断的な面で捉えた分裂病の特殊性について の知見で, 先の縦と横の関係から言えば, 縦断的 経過についての検討が明らかに不足している。 た実際の臨床場面において, 将来的に事象関連電 位を分裂病治療における機能的指標として活用し ていくためには, 臨床経過に即した検討が必要で あることは最初にも述べた。

亀山ら ${ }^{37}$ は, 分裂病患者 10 名について服薬前後 の 2 回でシラブル弁別課題遂行時の ERP を検討 し, N100・P200には服薬により channel selective attention の効果が認められたが, 服薬の前後で P300には変化が認められなかったと報告した。ま た Blackwood ら ${ }^{2} は, 24$ 名の分裂病患者につい て, 治療前・服薬 1 週後・服薬 4 週後について E $\mathrm{RP}$ を記録したものを比較し, 服薬 4 週目で BPR $\mathrm{S}$ 得点が減少した時点では, P300については結果 として変化がなかったとしている。しかしてれら の報告は, 福田ら ${ }^{38}$ が言及したように, 患者を群と して処理して検討したもので, 分裂病が多様な症 状と経過を示す疾患である以上, これだけで臨床 症状の変化との関連を規定してしまうには問題が 残る.そこで, 個々の患者における縦断的な検討 が必要となる. 松林 ${ }^{9}$ は, <精神病陽性症状期>の 分裂病患者 18 名について, 治療開始前之開始後 8 週目を個別に比較検討し, 精神症状の改善した者

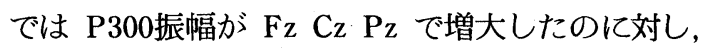
不変ないし悪化した者では逆に小さくなる, と報 告した. Duncan ${ }^{18)}$ ら 7 名の分裂病者において服 薬前後6.5週以上で 2 回の ERP を記録し, 薬物療 法の奏功した 1 名で P300振幅の増大が認められ たとしている. また駒田 ${ }^{19} ら も, 16$ 名の分裂病患者 を対象に, HPD 単独治療前後の 2 時点で ERP 
所見の比較を行い患者でとの検討では，P 300 成分 に関して, BPRS 得点が減少した者と陽性症状得 点の減少した者では振幅が増大し, 陰性症状得点 の減少した者では潜時が延長し $(\mathrm{Fz})$, 振幅は増大 した $(\mathrm{Fz} \mathrm{Cz})$ と報告している.しかし全体として 観察期間が若干短く, ERP 記録時期も微細な病 状の変化によらず，ほぼ一律にしたものが目立つ。 2 . 認知障害の改善性と病型

著者の方法による結果では, まず目標刺激時の ERP では, 症状が軽減した者あるいは良好な臨床 経過にある者のなかに, P300振幅が増大していく ものと, 低振幅のまま一定の傾向を示さないもの との 2 群が存在した. 前者は緊張型と妄想型の 2 型であり, 後者は解体型と残遺型の 2 型であった. この結果は前述の松林, Duncan ら, 駒田らの報 告を一部支持するが，乙となる点もある. 著者の 検討でも, 例えば解体型または残遺型の患者で, BPRS 得点の減少と P 300 振幅増大が一致した時 期もあり, ERP 記録時期を患者の病状によらず 一律にすると, 従来の報告に類似した可能性も考 えられる.いずれにせよ緊張型と妄想型分裂病に おいては, 治療によって精神症状が改善するとと もに, 認知障害も改善されていく可能性が示され た.また解体型と残遺型分裂病においては, 全体 として良好な経過にみえていても, 難治性の精神 症状が存在すると同時に, 認知障害においても治 療抵抗性があり, 相互に関連する可能性が示唆さ れた。

3. 経過からみた諸病型の認知様態

分裂病の諸病型における認知様態を, 経過に即 して文献的に考察すると, まず急性 (増悪) 期に おける諸説を内海 ${ }^{39}$ がまとめたところでは, 破瓜 型の増悪期ではひとつの対象が認識される場合, そこに含まれる様々なアスペクト（情勢）が成層 的に構造化されているが, その菲薄化が緩やかに 進行する，そして成層構造が全般に平板化し，認 知の場の文節化が希薄になって諸対象が容易に並 列化しやすい状態にあるが, 妄想型では同じ構造 の奥行きが菲薄化し, 構造的に下位のアスペクト

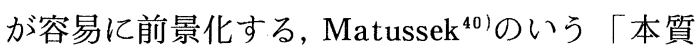

属性の優位」が認められるという。

慢性期の認知様態については数多くの優れた仮 説があるが, D.Shakow ${ }^{41}$ は慢性破瓜型分裂病の 基本障害は < major set（刺激全体に対する統合 された構え)>が維持できないことであり, 常に $<$ segmental set（一貫性がなく周縁的な刺激に とらわれやすい構え)>の侵入を受けるものであ ると帚結した. 同時に彼はパラノイド型（非破瓜 型, ないしは反応性分裂病に相当すると考えられ ている）分裂病について, 破瓜型と同様の解体傾 向を持ちながらそれを過鄱に代償しようとするた め, 対極的な認知様態をとるとした. Silverman ${ }^{42)}$ は, 認知テストに扔いて, 病前適応不良群（ほ添 破瓜型に相当）では場一依存的（知覚が知覚の 場の構造に依存してある要素を取り出すととがで きない）傾向力強く, 認知場の走査（個人の行う 認知的統制のうち広がりの次元）が限局化されて いるのに対し, 病前適応良好群（ほぼパラノイド 型に相当）では場一独立性（全体場を克服して, ある要素を取り出すことができる）が強く, 広範 な走查を行うことが認められるという.また Mc$\mathrm{Ghie}^{43}$ は, パラノイド型では選択的注意の障害が 認められず, むしろてれを強度に維持するとした。

以上の諸説から, 分裂病における急性期から慢 性期への経過を通じて, その認知様態は, 破瓜型 とパラノイド型（または妄想型）とで異なってい るととがわかる，そして今回の対象である分裂病 者も, 結果的に 2 分されるとととなった. 諸説と の関連でいえば, 解体型・残遺型が診断的にも破 瓜型に相当するとすれば, 緊張型・妄想型の認知 様態がパラノイド型のそれに類するものと考える ことができる.そしててれら 2 群の相違について いうならば, 認知の解体傾向の程度に違いがある と同時に, 別種の認知様態に基づく障害を有する ものであるといえよう.

\section{4. 社会適応状況と ERP}

個々の分裂病患者の臨床経過において各人の社 会適応状況に注目することは, 治療の指標として 症状の消裉以上に重要である.

今回の経過中の ERP 記録と社会適応度との 
検討では, 非目標刺激時のP P 300 成分の出現頻度 において, 各人の社会適応状況に応じた違いが認 められた. 内海 ${ }^{39}$ は諸説を総合して, 一般に分裂病 の急性期には共通して, 反応の七エラルキ一の崩 壞, あるいは関連あるもの（referent）と関連の ないもの (non-referent) の差異の消失によるゲ シュタルトの崩壊というような, 認知の構造の解 体した事態が考えられるとした。この意味から今 回の著者らの結果をかえりみると, 関連あるもの (target), すなわち目標刺激のみに反応するもの から, 関連のないもの (non-target), すなわち非 目標刺激でも差異無く反応してしまうもの, そし て関連のあるなしにかかわらず反応しないものま で, 言い換えると, 認知の構造の解体度が進むに 従って, 社会適応度も悪化している可能性が推察 された。

目標刺激時の ERP の検討では, 小林 ${ }^{44)}$ らが, 抗精神病薬服用中の分裂病者 40 名に対して社会適 応状態と P300成分との関係を調べ, 対照に比べ, 良好群・不良群ともに有意に潜時が延長していた こと, 振幅は不良群では, 対照と良好群の双方に 比べ有意に小さいこと等を報告している. 著者ら の結果では, 社会適応不良群における P 300成分 が, 健常対照群や良好群と比べて低振幅である時 期も認められたが, 経過を通じて一貫したもので はなく, 潜時に関しても一定の傾向は認められな かった。

最後に今後の課題として, まず ERP 各成分に 対する薬物の影響については現在一定の見解がな いが, 詳細に検討する必要のあること, そして今 後は計数課題のみでなく, 他の各種の課題によっ ても再現性があるか否か検討するてとが必要とな ろう. また今回は, 明確な傾向が $\mathrm{Pz}$ 導出に限定 された形となったが, 他の導出についても詳細な 検討が続けられるべきであろう.

\section{結 論}

さまざまな分裂病患者 10 名について, BPRS・S ANS 等を用いて臨床症状を評価しながら, odd- ball 課題による ERP を向精神薬未服薬の時点か ら縦断的に記録し, 分裂病の臨床経過と, N100成 分, P300成分の変化について検討した.

1. 緊張型と妄想型の各 2 例では, 臨床症状の軽快 とともに一貫して P300振幅の増大力認められた。

2 . 解体型と残遺型の各 3 例では, P 300振幅の変 化に一定の傾向は認められなかったが, 概して低 振幅であった。

3. 社会適応中間ないし不良群の 5 例では, 非目 標刺激時の $\mathrm{P} 300$ 成分が $\mathrm{Pz}$ 導出で, 社会適応良 好群または健常対照群に比べ高頻度で出現したが, 社会適応最不良群の 1 例では, 目標・非目標刺激 とも, 経過中 P 300 成分は認められなかった。

4.まとめ

A. 緊張型と妄想型では, 認知障害の治療反応 性が高い一方, 解体型と残遺型の認知障害には治 療抵抗性の要素があり, 緊張型および妄想型とは, 認知解体の程度や, 認知様態が異なる障害である 可能性が示唆された.

B. 非目標刺激時 P 300 成分の検討からは, 認 知構造の解体傾向が分裂病者の社会適応状況に影 響している可能性が考えられた。

稿を終えるにあたり，終始で指導とで助言を頂いた井 上令一教授に心から感謝の急を表します.またで校閲を 頂いた飯塚礼二教授, 永田俊彦助教授, さらにで協力頂 いた順天堂越谷病院の職員の皆様に深謝致します.

なお, 本研究の一部は, 第20回日本脳波・筋電図学会 学術大会, および第17回『性格・行動と脳波』研究会で 発表した。

\section{文献}

1 ) Sutton, S., Braren, M. and Zubin, J, : Evoked potential correlates of stimulus uncertainty. Science $150 ; 1187 \sim 1188,1965$

2) Blackwood, D.H.R., Whalley, L.J. and Christie, J.E. et al. : Changes in auditory $\mathrm{P}$ 3 event-related potential in schizophrenia and depression. Br. J. Psychiatry, 150; 154 160, 1987

3 ) Brecher, M. and Begleiter, H. : Event-rela- 
ted brain potentials to high incentive stimuli in unmedicated schizophrenic patients. Biol. Psychiatry, $20 ; 661 \sim 673,1983$

$4)$ Brecher, M., Porjetz, B. and Begleiter, H. : $\mathrm{N} 2$ component of the event-related potential in schizophrenic patients. Electroencephalogr. Clin. Neurophysiol, $66 ; 369 \sim 375,1987$ a

5 ) Baribeau-Braun, J., Picton, T. W. and Gosselin, J.Y. : Schizophrenia: A neurophysiological evaluation of abnormal information processing. Science, $219 ; 874 \sim 876,1983 \mathrm{~b}$

6 ) Duncan-Johnson, C. C., Roth, W.T. and Kopell, B.S. : Effects of stimulus sequence on P 300 and reaction time in schizophrenics. A preliminary report. Ann. NY Scad. Sci. 425; 570 577, 1984

7 ) 亀山知道, 平松謙一, 斎藤 治, 他 : シラブル弁別課 題遂行時の事象関連電位と選択的注意機能 (第 2 報). 精神経誌, 86 ; 501 524, 1984b

8 ) 松林 実, 小椋 力, 岸本 朗, 他 : 精神分裂病者の 事象関連電位一抗精神病薬服用中の慢性例について一 精神医学, $26 ; 607 \sim 612,1984$

9 ) 松林 実: 精神分裂病者の事象関連電位之認知機能. 米子医誌 J Yonago Med Ass, 35 ; 627 650, 1984

10) 三田俊夫, 橋本光彦, 切替辰哉, 他 : 精神疾患汇引け る事象関連電位の P300亿ついて。臨床脳波, $27 ； 167$ $\sim 175,1985$

11) Ogura, C., Nageishi, Y., Shimokochi, M. et al. : Evaluation of event-related potentials in schizophrenia using principal components analysis. Electroencephalogr. Clin. Neurophysiol. Suppl. , $40 ; 733 \sim 737,1987$

12) Pfefferbaum, A., Wenegrat, B. G., Ford, J.M. et al. : Clinical applications of the $\mathrm{P} 3$ component of event-related potentials. II . Dementia, depression and schizophrenia. Electroenceph . Clin. Neurophysiol., 59 ; 104 124,1984

13) Roth, W. T., Horvath, T. B., Pfefferbaum, A. et al. : Event-related potentials in schizophrenics. Electroencephalogr. Clin. Neurophysiol. $48 ; 127 \sim 139,1980 \mathrm{a}$

14) Roth, W. T., Pfefferbaum, A., Horvath, T.B. et al. : P3 reduction in auditory evoked potenti- als of schizophrenics. Electroencephalogr. Clin. Neurophysiol. , 49 ; 497 505 1980b

15) Roth, W. T., Pfefferbaum, A., Kelly, A.F. et al. : Auditory event-related potentials in schizophrenia and depression. Psychiat. Res., 4 ; 199 $\sim 212,1981$

16）斎藤 治, 亀山知道, 平松謙一, 他 : Dichotic detection 課題遂行時の事象関連電位と分裂病患者の選択 的注意の障害. 精神経誌, $85 ; 31 \sim 53,1983$

17）平松謙一, 秋本 優, 丹羽真一, 他 : 選択反応課題红 おける分裂病患者の反応時間と P 300 潜時一適応形相 関フィルタを用いた 1 試行毎の P 300成分の推定. 精 神医学, $27 ; 1055 \sim 1063,1985$

18) Duncan, C. C., Morihisa, J. M., Fawcet. R.W. et al. : P 300 in schizophrenia : State or Trait Marker? Psychopharmacology Bull. , 23 ; 497 501,1987

19）駒田有彦, 岸本 朗, 小林孝文, 他：ハロペリドール 治療に伴う事象関連電位の変化. Neurosciences, 14 ; $66 \sim 68,1988$

$20 ）$ 江熊要一: 精神分裂病寛解者の社会適応の破綻をい かに防止するか 精神経誌,64; 921〜927, 1962

21）橋本俊明, 井口 喬, 奥山清一 : 大都市における精 神分裂病の病院内医療と地域ケアについて一その実 態と未来像. 社会精神医学, 10; 145 153, 1987

22）一宮祐子, 石川一郎, 小林節夫, 他: 精神分裂病の転 帰一定型的分裂病 129 例の 20 年以上継続観察 [ I ]. 精 神経誌,88；206〜234, 1986

23）誘発電位測定指針 (案)：脳波と筋電図, $13 ； 97$ 104, 1985

24) Conrad, K. : Die beginnende Schizophrenie. Georg Thieme, Stuttgart, 1958

25) Shagass, C. : Early evoked potentials. Schizophr. Bull., $3 ; 80 \sim 92,1977$ a

26) Obios, J.E., Bachs, J.S. and Masana, J. : Event-related potentials in young chronic schizophrenics. Biol. Psychiatry, 21; 856 859, 1986

27) Hillyard, S. A., Hink, R.F., Schwent, V.L. et al. : Electrical signs of selective attention in human brain. Science, $182 ; 177 \sim 180,1973$

28) Hink, R. F., Hillyard, S. A. and Benson, P. J. : Event-related brain potentials and selective attention to acoustic and phonetic cues. Biol. Psy- 
chol., $6 ; 1 \sim 16,1978$

29) Donchin, E., Ritter, W., and McCallum, W.C. : Cognitive psychophysiology : the endogenous components of the ERP in Callaway, E., Tueting, P., and Koslow, S. (ed.) Event-related Brain Potentials in Man. Academic Press, New York, pp349 442, 1978

30) Kutas, M., McCarthy, G. and Donchin, E. : Augmenting mental chronometry : The P300 as a measure of stimulus evaluation time. Science, $197 ; 792 \sim 795,1977$

31) McCarthy, G. and Donchin, E. : A metric for thought ; A comparison of $\mathrm{P} 300$ latency and reaction time. Science, $211 ; 77 \sim 80,1981$

32) 平松謙一, 亀山知道, 斎藤 治, 他 : シラブル弁別課 題遂行時の事象関連電位之選択的注意機能 (第 1 報) 一正常者の結果について. 精神経誌, 86 ; 120 143, 1984

33) Donchin, E. : Event-related brain potentials : A tool in the study of human information processing. In Begleiter, H. (ed)Evoked Brain Potentials and Behavior. Plenum Press, New York. : $1 \sim 88,1979$

34) Magliero, A., Bashore, T.R., Coles, M. G. H. et al. : On the dependence of P300 latency on sti mulus evaluation process. Psychophysiology, $21 ; 171 \sim 186,1984$

35）平松謙一, 秋本 優, 丹羽真一, 他 : 健常者における P300潜時と選択反応時間の相関一適応形相関フィル 夕による P 300潜時の推定. 臨床脳波, 27；237〜243,
1985

36) 斎藤 治, 丹羽真一, 平松謙一, 他 : 精神分裂病の認 知障害. 臨床精神医学, $14 ; 891 \sim 906,1985$

37）亀山知道, 丹羽真一, 平松謙一, 他 : 分裂病の注意・ 認知障害に対する向精神薬の効果の生理学的検討一事 象関連電位を指標として一精神薬療基金研究年報, 第 16集, 1985

38) 福田正人, 丹羽真一, 平松謙一, 他 : 脳の生理・生化 学的機能評価; 分裂病治療のための機能評価. 臨床精 神医学,18（2）；157〜 165, 1989

39) 内海 健: 精神分裂病一基礎と臨床一 (木村敏, 松 下正明, 岸本英爾編), 朝倉書店, 東京 ; $87 \sim 95,1990$

$40)$ Matussek, P. : Untersuchungen über die Wahnwarnehmung. 2. Mitteilung : Der abnorme Vorrang von Wesenseigenschaften. Schweiz. Arch. Psychiatr. 71, 89. 1953

41) Shakow, D. : Segmental set : A theory of the formal psychological deficit of schizophrenia. Arch Gen Psychiatr., 6 ; 17 33, 1962

42) Silverman, J. : The problem of attention in research and theory in schizophrenia. Psychol. Rev. 71 ; 352 379, 1964

43) McGhie, A. : Attention and perception in schizophrenia. Progress in Experimental Personality Research Vol. 5 (ed Maher BA), Academic Press, New York, 1970

44) 小林孝文, 岸本 朗, 鎌田 修, 他 : 精神分裂病者の 社会適応と P 300 成分. 教室開講40周年 挟間秀文教授 就任10周年記念論文集 (鳥取大学医学部神経精神医学 教室）；24 32, 1985 
Original Paper

\section{Summary}

Changes in event-related potentials during the course of schizophrenia

In 10 patients with schizophrenia diagnosed by the DSM III-R, we repeatedly recorded the Event-Related Potentials (ERP) based on the odd-ball task, and estimated in great detail their clinical symptoms by using the Brief Psychiatry Rating Scale (BPRS) and the Score for the Assessment of Negative Symptoms (SANS) from the time in which psychotropic drugs were not taken to the time of their remission. Then I longitudinally evaluated the changes of N100 and P300 component during the course of schizophrenia.

In patients with catatonic type 2 and paranoid type 2 , the P 300 amplitude tended to be augumented with the remission of their symptoms, whereas in patients with disorganized type 3 and residual type 3 , the changes in P300 amplitude were mostly low without having a fixed relation with the change of symptoms. Also, in the intermediate to low level group of social adaptation as compared to high level groups, the P 300 component frequently appeared in the ERP when non-target stimulation was made. Also in the lowest level group, the P 300 component was not observed at the stimulation of either the target or non-target.

In the cognitive disorder of schizophrenia, therapeutic responsibility was high in the catatonic type and paranoid type whereas in the disorganized type and residual type there was a thrapy-resistant factor in which the pathological state was thought to be different from the former types. And from the evaluation of P 300 when non-target stimulation was made, the disorganizing degree of cognitive structures was suggested to affect the social adaptation level.

Key words : the course of schizophrenia, social adaptation level, event-related potentials, P300

Hideo FUMIMOTO, M. D. Department of Psychiatry, Juntendo University School of

Medicine, Tokyo, Japan 